\title{
Thema: Eerste ervaringen met IFRS
}

Voor beursgenoteerde ondernemingen in Europa was de jaarrekening 2005 een bijzondere gebeurtenis. Voor het eerst diende de geconsolideerde jaarrekening te worden opgemaakt in overeenstemming met de International Financial Reporting Standards (IFRS). Tot en met de jaarrekening 2004 werden bijna overal nog de nationale standaarden toegepast. Uniforme verantwoordingsregels voor de organisaties die in het openbaar kapitaal aantrekken zijn een belangrijke stap naar een geïntegreerde Europese kapitaalmarkt. Door de veel betere vergelijkbaarheid van jaarrekeningen, die met de invoering van IFRS is gerealiseerd, kan iedere analist en belegger in beginsel zonder problemen over de grenzen kijken.

Aan de andere kant kan niet worden verwacht dat IFRS de oplossing is voor alle verslaggevingsvraagstukken. Er zijn verschillende interpretaties mogelijk waardoor de vergelijkbaarheid vermindert. Ook bevat IFRS veel subjectieve elementen zoals reële waarden (zie MAB-themanummer, september 2003) en impairment (zie MAB-themanummer, juni 2004), waardoor er onzichtbare verschillen in verslaggeving bestaan. IFRS is complex en kostbaar, er is inconsistentie tussen verschillende standaarden, IFRS is meer rules-based dan we in Nederland gewend waren, en niet altijd leidt IFRS tot betere verslaggeving (Hoogendoorn, 2003, 2006, Ernst \& Young, 2006). Maar waar een analist wellicht wat inlevert op het inzicht in de absolute resultaten en financiële situatie van de individuele onderneming, daar verkrijgt hij in het algemeen een beter inzicht in de relatieve positie van de individuele onderneming ten opzichte van andere Europese (en niet-Europese) ondernemingen.

In deze MAB-special zijn zes artikelen opgenomen die samenhangen met de eerste ervaringen met IFRS. In het eerste artikel van Van der Tas, die als Nederlands lid van IFRIC de ontwikkelingen van zeer nabij heeft meegemaakt, wordt een overzicht gegeven van de achtergronden, kansen en bedreigingen inzake IFRS in Europa. Hij schetst in het algemeen een redelijk positief beeld, waarin hij aangeeft dat uit onderzoek blijkt dat kapitaalmarkten daadwerkelijk beter gaan functioneren als gevolg van IFRS, hetgeen kan leiden tot lagere vermogenskosten en betere beleggingsbeslissingen. Wel plaatst Van der Tas enkele kanttekeningen. Met name ziet hij op langere termijn grenzen in de toepassing van reële waarden, vooral daar waar de betrouwbaarheid van financiële informatie in het geding kan komen.

Het tweede artikel van Delger en Koster, beiden werkzaam bij de AFM, bespreekt specifiek de rol van de toezichthouders bij de toepassing van IFRS. Voor Nederlandse ondernemingen is het toezicht op de financiële verslaggeving een nieuw verschijnsel. Hoewel IFRS een uniforme standaard is die gelijk is voor alle ondernemingen, is het toezicht tot nu toe nog nationaal geregeld. Delger en Koster gaan in hun artikel met name in op de Europese afstemming tussen de nationale toezichthouders, binnen het Committee of European Securities Regulators (CESR). Zij beschrijven op welke wijze de nationale toezichthouders onder de coördinatie van CESR kunnen bijdragen aan een consistente toepassing van IFRS. Uiteindelijk zal dit naar de verwachting van de auteurs resulteren in één Europese toezichthouder. In het derde artikel van Vergoossen wordt verslag gedaan van een empirisch onderzoek naar de jaarrekeningen 2005 van 45 Nederlandse en 44 buitenlandse beursgenoteerde Europese ondernemingen. Uit dit onderzoek blijkt dat de invloed op de gepresenteerde winst- en vermogenscijfers sterk uiteenloopt. In de meeste gevallen leidt de eerste toepassing van IFRS tot een lager eigen vermogen en een hoger nettoresultaat. De verschillen tussen nationale standaarden en IFRS hebben vooral betrekking op pensioenen, goodwill, winstbelastingen, voorzieningen, financiële instrumenten en op aandelen gebaseerde betalingen. Van de uitzonderingsbepalingen van IFRS 1 is veel gebruik gemaakt.

Het vierde en vijfde artikel gaan in op economische consequenties van IFRS. Al eerder is in het MAB aandacht besteed aan de gevolgen van IFRS op de 
aantrekkelijkheid van preferente aandelen (De Jong, Rosellón en Verwijmeren, 2006). In dit themanummer komen de gevolgen voor de pensioenregelingen aan de orde in een artikel van Swinkels en de gevolgen voor de mogelijkheid en uitoefening van resultaatsturing ('earnings management') in een artikel van Heemskerk en van der Tas.

Swinkels stelt zich de vraag of pensioenregelingen zijn gewijzigd als gevolg van de introductie van IFRS. Een aantal ondernemingen heeft een toegezegdepensioenregeling ('defined benefit'- regeling) omgezet in een (collectieve) toegezegde-bijdrageregeling ('defined contribution'), waarbij als officiële verklaring de invoering van IFRS wordt aangegeven. Toch blijkt de overgang naar toegezegde-pensioenregelingen (nog) maar beperkt te zijn, wel hebben veel ondernemingen hun eindloonregeling in een middelloonregeling omgezet.

Heemskerk en van der Tas zijn nagegaan of de mate van resultaatsturing (waaronder winstegalisatie) bij ondernemingen die in het verleden zijn overgegaan op IFRS is gewijzigd. Resultaatsturing heeft in het algemeen een negatieve invloed op de transparantie en vergelijkbaarheid van financiële verslaggeving. Verwacht werd dat door de striktere regelgeving IFRS zou leiden tot minder resultaatsturing. De resultaten van het onderzoek wijzen echter eerder op een stijging. De verklaring hiervoor hangt samen met de volatiliteit in de resultaten die ontstaat als gevolg van toepassing van de strikte regels: de volatiliteit wordt door het management als ongewenst beschouwd en deze wordt afgezwakt met behulp van de invulling van de subjectieve schattingen die inherent zijn aan de toepassing in IFRS (in het bijzonder de bepaling van reële waarden).

Het zesde en laatste artikel is in alle opzichten het sluitstuk. De hele introductie van IFRS in Europa is uiteindelijk gericht op de gebruiker. Kamp gaat in zijn artikel na welke gevolgen IFRS heeft op het gedrag en de oordeelsvorming van financieel analisten. De grote lijn lijkt volgens hem te zijn dat de invoering van IFRS weinig invloed heeft gehad op de oordeelsvorming van analisten. Wel komen de solvabiliteitsratio's mogelijk op een structureel ander niveau te liggen, met mogelijke gevolgen voor het gebruik van benchmarks. Analisten lijken meer nadruk te leggen op kasstromen in plaats van op winstcijfers en grote veranderingen in gepresenteerde winstcijfers, zoals het niet meer afschrijven op goodwill, lijken nauwelijks invloed te hebben op de beleggingsanalyse. Kamp concludeert, anders dan Van der Tas, dat IFRS kennelijk nog niet heeft geleid tot lagere vermogenskosten.
Ik denk dat dit themanummer een rijk en gevarieerd overzicht geeft van de eerste ervaringen met IFRS. Het leidt tot een wat gemengd beeld. Het is duidelijk dat IFRS niet meer weg te denken is in Europa, maar het is nog niet duidelijk wat nu exact de consequenties zijn voor de oordeelsvorming van analisten en voor de vermogenskosten. Aan de ene kant leidt de verbetering van de vergelijkbaarheid sec tot een verlaging van de vermogenskosten, aan de andere kant lijkt dit effect te worden geneutraliseerd door de subjectiviteit die IFRS kenmerkt en die leidt tot een grotere mate van winststuring. Ook op zichzelf hoeft meer transparantie niet te leiden tot verlaging van vermogenskosten, namelijk als daardoor 'verborgen zwakheden' zichtbaar worden. Voorts hebben economische consequenties in de vorm van het beëindigen of herstructureren van preferente aandelenfinanciering en van de omzetting van pensioenregelingen direct effect op de kasstromen. Een ander voorbeeld is de invloed van IFRS op de antrekkelijkheid van personeelsopties als beloningsinstrument (zie bijvoorbeeld Knoops en Vergoossen, 2006). Ook de goodwillimpairment methode, waardoor overnames een directe bijdrage leveren aan een verhoging van de winst per aandeel, kan belangrijke economische consequenties hebben voor de overnameactiviteit en voor de prijs die men bereid is te betalen. Anders dan bij pensioenregelingen kan IFRS hier het risicoprofiel van de onderneming mogelijk vergroten. Meer onderzoek moet hier duidelijkheid in brengen. In dit themanummer hebben we ons noodzakelijkerwijs moeten beperken tot de eerste ervaringen. Het spreekt vanzelf dat in toekomstige nummers van het $\mathrm{MAB}$ ruim aandacht zal worden besteed aan verdere ervaringen met de toepassing van IFRS.

Namens de redactie: Martin Hoogendoorn

\section{Literatuur}

Ernst \& Young (2006), Observations on the Implementation of IFRS, september; zie: www.ey.com/global.

Hoogendoorn, M.N. (2004), Regels over regels, Hoe effectief is de International Accounting Standards Board, oratie Erasmus Universiteit Rotterdam, Kluwer.

Hoogendoorn, M.N. (2006), 10 IFRS-lessen, De Accountant, no. 10, juni, pp. $36,37$.

Jong, A. de, M.A. Rosellón en P. Verwijmeren (2006), De invloed van IFRS op preferente aandelen in Nederland, Maandblad voor Accountancy en Bedrijfseconomie, jg. 80, no. 7/8, juli/augustus, pp. 336-342.

Knoops, C.D. en R.G.A. Vergoossen (2006), IFRS, cijfermatige invloed en economische gevolgen, in: R. Bosman, C. Camfferman en R.G.A. Vergoossen (redactie), Het jaar 2005 verslagen, Koninklijk NIVRA / Kluwer, Deventer. 